\title{
Reducing geosmin off-flavor compounds and waste outputs through dietary phosphorus management in rainbow trout aquaculture
}

\author{
Pallab Sarker ${ }^{1,3, *}$, Alexandre Pilote ${ }^{1}$, Marc Auffret ${ }^{2}$, Émilie Proulx ${ }^{1}$, \\ Richard Villemur ${ }^{2}$, Marie-Hélène Deschamps ${ }^{1}$, Grant Vandenberg ${ }^{1}$ \\ ${ }^{1}$ Département des sciences animales, Université Laval, Québec City, Québec G1V 0A6, Canada \\ ${ }^{2}$ INRS-Institut Armand-Frappier, 531 Boulevard des Prairies, Laval, Québec H7V 1B7, Canada \\ ${ }^{3}$ Present address: Environmental Studies Program, Dartmouth College, Hanover, New Hampshire 03755, USA
}

\begin{abstract}
The aquaculture industry has long recognized the need to reduce phosphorus (P) waste outputs associated with environmental impact, and reduce off-flavor producing compounds, which can impact the quality of the fish product. This study was undertaken to investigate the effects of dietary high P (HP) and low P (LP) on growth, nutrient digestibility, P retention, and $P$ loading as well as their correlation to the synthesis of geosmin-associated off-flavor in a recirculating aquaculture system of rainbow trout Oncorhynchus mykiss. The above diets were fed to quadruplicate tanks of rainbow trout (average mass \pm SD: $127.4 \pm 3.1 \mathrm{~g}$ ) for $84 \mathrm{~d}$. Results showed that the effects of the HP and LP diets on growth and P retention were not significantly different. While the apparent digestibility of $\mathrm{P}$ and other nutrients were higher in fish fed the LP diet, $\mathrm{P}$ waste outputs and geosmin levels in the fillets of fish were higher in fish fed the HP diet. Magnesium $\left(\mathrm{Mg}^{2+}\right)$, potassium $\left(\mathrm{K}^{+}\right)$and zinc $\left(\mathrm{Zn}^{2+}\right)$ concentrations in tank water were significantly lower in fish fed the HP diet than the LP diet in most of the sampling events. Furthermore, the tank water geosmin concentration was not strongly proportionally correlated with tank water-soluble P concentration for both the LP and HP diets. There was a strong proportional linear relationship between the geosmin concentration in tank water and in trout fillet for both the LP and HP diets. Results suggest that off-flavor contents in fish fillets and water were related to the dietary P level and metabolic $\mathrm{P}$ waste outputs into the system, findings that have implications for the formulation of sustainable diets for rainbow trout.
\end{abstract}

KEY WORDS: Recirculating aquaculture system - Metabolic phosphorus waste Off-flavor · Geosmin $\cdot$ Oncorhynchus mykiss $\cdot$ Growth $\cdot$ Nutrient digestibility $\cdot$ Nutrient retention

\section{INTRODUCTION}

The presence of off-flavors in fish raised in recirculating aquaculture systems (RAS) represents one of the most significant economic problems related to product quality encountered in aquaculture. The presence of undesirable odors or tastes in fish may cause a major reduction in human consumption of the products, or make them unsuitable for sale. Among those flavors, the 'earthy' and 'muddy' odors constitute $>80 \%$ of the off-flavor problems

*Corresponding author: pallab.k.sarker@dartmouth.edu found in farm-raised catfish (Grimm et al. 2000). Such off-flavors come from the absorption by fish of substances including geosmin and 2-methylisoborneol (2-MIB), which are produced by a broad group of aquatic microorganisms (Gerber 1969, Tucker 2000, Bai et al. 2013). In our previous RAS studies, negligible MIB concentrations were found in fillets of arctic charr and rainbow trout; these studies also clearly revealed that off-flavor was caused mainly by geosmin (Auffret et al. 2011, Houle et al. 2011).

(C) The authors 2014. Open Access under Creative Commons by Attribution Licence. Use, distribution and reproduction are unrestricted. Authors and original publication must be credited. 
Elevated phosphorus (P) levels in freshwater aquaculture effluents may lead to environmental problems (Schindler 1977, Camargo \& Alonso 2006), as intensive aquaculture can generate environmental P loading that may contribute to the eutrophication of sensitive receiving water bodies (Lall 1991, Sarker et al. 2013). Furthermore, it is often claimed that eutrophic waters are the most vulnerable to off-odors. The environmental factors known to lead to high levels of geosmin by producing nuisance blooms of some microorganisms, such as streptomycetes, myxobacteria and cyanobacteria, include high nutrient concentrations and ratios (Smith \& Bennett 1999, Downing et al. 2001, Robin et al. 2006, Schrader \& Summerfelt 2010).

A number of investigators have reported that $\mathrm{P}$ concentration correlates with geosmin concentration (Saadoun et al. 2001, Robertson et al. 2006, Robin et al. 2006, Dzialowski et al. 2009). Since the majority of P released by aquaculture operations is ultimately from dietary origin, effective management of waste outputs can be achieved through management of the nutrient composition of feeds. However, the literature lacks data on whether dietary $\mathrm{P}$ and the consequential metabolic wastes can induce geosmin-associated off-flavor in RAS-raised rainbow trout. Our recent preliminary studies demonstrated that geosmin-associated off-flavor in rainbow trout correlates to elevated $\mathrm{P}$ levels in feed, resulting in the excretion of excess $\mathrm{P}$ into the water (authors' unpubl.). We hypothesize that a high-P trout feed may induce geosmin-associated off-flavor in rainbow trout raised in RAS. The purpose of the current study is to investigate the effects of dietary $\mathrm{P}$ levels on the synthesis of geosmin in water and trout fillet. In particular, our goal is to evaluate a low-P (LP) diet containing $5.4 \mathrm{~g} \mathrm{~kg}^{-1}$ total $\mathrm{P}$ and a high-P (HP) diet containing $13.0 \mathrm{~g} \mathrm{~kg}^{-1} \mathrm{P}$ using the response criteria of weight gain, nutrient digestibility, $\mathrm{P}$ retention, $\mathrm{P}$ waste outputs and geosmin concentrations in trout fillet and water.

\section{MATERIALS AND METHODS}

\section{Experimental diets, fish rearing, feeding and design}

Two iso-nitrogenous and iso-energetic diets were formulated, all based on the same basic feed containing balanced levels of essential amino acids, fatty acids, vitamins and minerals, except for $\mathrm{P}$ and calcium (Ca) levels (Table 1). The 2 practical diets contained 5.4 and $13.0 \mathrm{~g} \mathrm{~kg}^{-1}$ total P (LP and HP, respectively). The HP is closest to that of standard fish feed for rainbow trout. The HP diet was obtained by supplementing 3.5\% inorganic phosphorus salt (i.e. $35 \mathrm{~g} \mathrm{CaHPO}_{4} \mathrm{~kg}^{-1}$ ) in the basal diet. Rainbow trout Oncorhynchus mykiss (initial average mass: $127.4 \pm 3.1 \mathrm{~g}$ ) was used. The experimental set-up was arranged in a completely randomized design; each diet was fed to 4 replicate rectangular tanks (380 l volume), each containing 43 fish. The feeding experiment was conducted in an RAS

Table 1. Oncorhynchus mykiss. Experimental diet formulation (as fed basis) and chemical composition (dry matter basis). Vitamin premix and mineral premix: supplied the following: as per NRC (1993) (to provide mg kg${ }^{-1}$ except as noted): retinyl acetate, $2500 \mathrm{IU}$; cholecalciferol, $2400 \mathrm{IU}$; tocopheryl acetate, 50; menadione, 10; thiamin, 1; riboflavin, 4; pyridoxine, 3; Ca-pantothenate, 20; vitamin B-12, 0.01; niacin, 10; biotin, 0.15; folic acid, 1; choline, 1000; inositol, 300; magnesium carbonate, $1.24 \mathrm{~g}$; calcium carbonate, $2.15 \mathrm{~g}$; potassium chloride, $0.90 \mathrm{~g}$; sodium chloride, $0.40 \mathrm{~g}$; potassium iodide, 0.4 ; copper sulfate, 30 ; cobalt sulfate, 0.2 ; ferric sulfate, $0.20 \mathrm{~g}$; manganese sulfate, 30; zinc sulfate, 40; sodium fluoride, 10. Digestible phosphorus $(\mathrm{P})=$ Total $\mathrm{P}$ in the diet $\times \mathrm{P}$ digestibility/100

\begin{tabular}{|c|c|c|c|}
\hline & \multicolumn{2}{|c|}{$\begin{array}{c}\text { Diet } \\
\text { Low } \mathrm{P} \text { High } \mathrm{P}\end{array}$} & Canadian supplier \\
\hline \multicolumn{4}{|l|}{ Ingredients $\left(\mathrm{g} \mathrm{kg}^{-1}\right)$} \\
\hline Herring meal & 75 & 75 & SANIMAX \\
\hline $\begin{array}{l}\text { Blood meal (non-ruminant; } \\
\text { APC Inc. AP 301) }\end{array}$ & $; 100$ & 100 & SANIMAX \\
\hline Feather meal & 100 & 100 & Floradale Feed Mill \\
\hline Wheat grain & 205 & 180 & Meunerie Gérard Soucy \\
\hline Soybean meal ( $46 \%$ ) & 80 & 80 & Meunerie Gérard Soucy \\
\hline Wheat gluten & 70 & 70 & ADM Alliance Nutrition \\
\hline Corn gluten meal & 170 & 170 & Meunerie Gérard Soucy \\
\hline Fish oil & 180 & 180 & SANIMAX \\
\hline $\begin{array}{l}\mathrm{CaHPO}_{4} \text { (Laboratoire } \\
\text { mat, CR-0118) }\end{array}$ & 0 & 35 & Meunerie Gérard Soucy \\
\hline Lysine (Biolys) & 12 & 12 & SANIMAX \\
\hline DL-methionine & 2 & 2 & Corey Feed Mills \\
\hline $\begin{array}{l}\text { Vitamin premix and } \\
\text { mineral premix }\end{array}$ & 6 & 6 & Corey Feed Mills \\
\hline $\begin{array}{l}\text { Antioxidant (ppm) } \\
\text { (ethoxiquin 0.015\%) }\end{array}$ & 100 & 100 & Corey Feed Mills \\
\hline \multicolumn{4}{|c|}{ Proximate composition ( $\%$ as dry matter) } \\
\hline Dry matter & 90.45 & 90.18 & \\
\hline Crude protein & 49.71. & 49.93 & \\
\hline Lipid & 20.79 & 21.39 & \\
\hline Energy (MJ kg ${ }^{-1}$ ) & 24.93 & 24.43 & \\
\hline Total phosphorus & 0.54 & 1.30 & \\
\hline Digestible phosphorus & 0.32 & 0.69 & \\
\hline Ash & 4.16 & 7.11 & \\
\hline
\end{tabular}


system at the Laboratoire Régional des Sciences Aquatiques (LARSA), Université Laval. The recirculation rate was $>90 \%$. The flow of makeup water, which was from a municipal source, dechlorinated and filtered $(45 \mu \mathrm{m})$, was fixed at $20 \mathrm{l} \mathrm{h}^{-1}$ for a retention time of $3.5 \mathrm{~d}$. Oxygen concentration (90-100\% saturation) and water temperature $\left(15.0^{\circ} \mathrm{C}\right)$ were monitored in real-time throughout the experiment. The pH (7.4) was measured once daily and sodium carbonate was added to maintain $\mathrm{pH}$ above neutral.

Prior to the beginning of the growth trial, fish were acclimated for $2 \mathrm{wk}$ with the LP diet. Tank by tank basis pair-feeding was employed to supply the same quantity of dietary nutrients (feed) to the groups, but $\mathrm{P}$ supply was variable, as the dietary $\mathrm{P}$ content of the 2 diets differed. LP replicates were hand-fed until apparent satiation 2 times a day, and the same quantity was fed to HP replicates. The experimental design and protocols were approved by the Canadian Council on Animal Care (CCAC 1984) and the Animal Protection Committee of Université Laval (CPAUL 2010).

For the digestibility measurement of the diet, $1 \%$ Sipernat $50^{\mathrm{TM}}$ (a source of acid-insoluble ash [AIA]) was added to the diet as an indigestible marker. Microingredients were first mixed and then slowly added to the macroingredients to ensure a homogeneous mixture. The ingredients were thoroughly mixed and steam-pelleted using a California Pellet Mill, and pellets were dried in a forced-air oven $\left(22^{\circ} \mathrm{C}, 24 \mathrm{~h}\right)$, sieved and stored at $-20^{\circ} \mathrm{C}$.

\section{Growth measurement and fish fillet preparation}

Fish were bulk-weighed at the beginning of the experiment, and then every $3 \mathrm{wk}$ until the end of the experiment $(84 \mathrm{~d})$. At the start of the experiment, 5 fish were sampled from the initial population; after which 3 fish per tank were sampled every $21 \mathrm{~d}$ (Days 0, 21, 42, 63 and 84). The effects on growth were determined by evaluating gain in fish mass, total feed consumption, specific growth rate (SGR), feed conversion ratio (FCR) and thermal-unit growth coefficient (TGC). Indices were calculated as follows:

Gain in fish mass $=[($ Final body mass -

Initial body mass) / Initial body mass] $\times 100 \%$

$$
\begin{aligned}
\mathrm{FCR}= & \text { Feed intake } / \text { Body mass gain } \\
\mathrm{SGR}= & 100 \times(\text { ln Final body mass }- \\
& \ln \text { Initial body mass }) / \text { Days } \\
\mathrm{TGC=} & 100 \times\left(\text { Final mass }{ }^{1 / 3}-\text { Initial mass }^{1 / 3}\right) / \\
& \text { Sum of daily water temperature }
\end{aligned}
$$

At each sampling event, length and weight were determined, fish were immediately filleted and the skin removed. Two fillets per fish were stored in a Ziploc bag at $-20^{\circ} \mathrm{C}$ for further geosmin (using solid phase micro extraction [SPME] with GC-MS) and lipid analysis.

\section{Water sample collection}

At every sampling time point, 3 water samples were taken in each tank from 3 different places. Individual water samples were stored in $20 \mathrm{ml}$ glass scintillation vials, $6 \mathrm{~g}$ of $\mathrm{NaCl}$ and a magnetic stir bar were then added just prior to analysis. The vials were filled completely, as indicated by the fact that no air bubbles were observed when the vial was capped and inverted, and were then stored at $4^{\circ} \mathrm{C}$ for further geosmin analysis. Geosmin concentration was analyzed the day after the sampling to avoid any reduction of geosmin content of the samples. At every sampling time point, 3 water samples were collected from different places of each sand filter, biofilter and pump using $20 \mathrm{ml}$ glass scintillation vials, and were stored at $4{ }^{\circ} \mathrm{C}$ for further geosmin analysis. To determine the concentration of soluble reactive phosphorus, anions and cations that had accumulated in the tank, sand filter, biofilter and pump water filter, water samples were collected in triplicate into a disposable $15 \mathrm{ml}$ falcon tube (containing $2 \mathrm{mM} \mathrm{HCl}$ ) (Falcon ${ }^{\circledR}$, Becton Dickinson) on Days 0, 21, 42, 63 and 84. Samples were stored at $4^{\circ} \mathrm{C}$ for further analysis.

\section{Fecal collection}

Feces were collected at the end of the feeding trial once a day for 2 wk via a modified Guelph system based on Cho et al. (1982) before the morning meal. Tanks were brushed and purged immediately and any uneaten feed residues and feces were flushed out of the fecal collection column after each feeding. The feces were decanted, excess water was removed and then the feces were stored at $-20^{\circ} \mathrm{C}$ until the end of the $2 \mathrm{wk}$ of feces collection. Feces were freezedried for $7 \mathrm{~d}$ prior to analysis to determine apparent digestibility coefficients (ADCs) for the nutrients.

\section{Diet and feces chemical composition}

A pool of different feed sizes was collected for analysis of the feeds. Dry matter, ash, crude pro- 
tein, total lipid, and gross energy in feed and feces were analyzed according to standard procedures (AOAC 1990). Fillet dry matter was obtained by first drying the pools in a lyophilizer for $7 \mathrm{~d}$, and then in a forced-air oven at $105^{\circ} \mathrm{C}$ overnight. Sample weight was recorded before and after drying, followed by cooling in a desiccator (AOAC 1990). Feed and feces dry matter was obtained by drying only in the forced-air oven. Ash content was obtained by dry-ashing in porcelain crucibles in a furnace at $500^{\circ} \mathrm{C}$ overnight and expressed as dry weight (AOAC 1990). Gross energy was performed by bomb calorimetry (Parr Instrument Company) and calculated as percentage of dry matter. Crude protein was evaluated using a LECO analyzer (model FP-2000), then a nitrogen (N) conversion factor of $\mathrm{N} \times 6.25$ was used, with crude protein expressed as dry weight.

Total lipid composition was performed with an Ankom lipid extraction instrument (XT-10, Ankom Technologies), the solvent being diethyl ether. Total lipids were expressed as dry weight. To determine the phosphorus concentration, acid digestion with $5 \mathrm{ml}$ concentrated $\mathrm{HNO}_{3}$ and $12.5 \mathrm{ml} \mathrm{HCl} \mathrm{(50 \% )} \mathrm{solu-}$ tion was used, and then resulting materials were filtered (Whatman paper No. 1) and then measured using an ion chromatography system (Dionex, ICS3000).

Nutrient ( $\mathrm{P}, \mathrm{N}$ and energy) retention was calculated as:

Nutrient retention $\left(\mathrm{g} \mathrm{kg}^{-1}\right.$ fish $)=100 \times[$ (Final biomass $\times$ Final nutrient concentration of the fish) - (Initial biomass $\times$ Initial nutrient concentration of the fish)] / Feed consumed $\times$ Nutrient concentration of the diet

Total P loading was estimated based on solid and dissolved P loading (solid P load + dissolved $\mathrm{P}$ load). Solid and dissolved nutrient ( $\mathrm{P}, \mathrm{N}$ and energy) load was calculated as follows:

Solid nutrient load $\left(\mathrm{g} \mathrm{kg}^{-1}\right.$ fish $)=[1$ - Apparent nutrient digestibility coefficient $\times$ Nutrient intake $\left(g \mathrm{~kg}^{-1}\right.$ fish)]

Dissolved nutrient load $\left(\mathrm{g} \mathrm{kg}^{-1}\right.$ fish $)=$ Apparent nutrient digestibility coefficient $\times$ [Nutrient intake (g kg ${ }^{-1}$ fish) - Retained nutrient ( $\mathrm{g} \mathrm{kg}^{-1}$ fish) $\left.]\right\}$

AIA in diets and feces were determined according to the official methods described by Keulen \& Young (1977). The ADCs of P were calculated as described by Cho \& Slinger (1979) using the following formula:

$\mathrm{ADC}=100 \times[1-(\%$ Nutrient of feces $/ \%$ Nutrient of diet $) \times(\%$ Marker in diet / \% Marker in feces $)]$

\section{Geosmin assay}

The method of Lloyd \& Grimm (1999) was used to analyze geosmin and MIB from the fillets and was modified as follows. Each fillet was placed into a glass distillation flask. The flask was then heated in a microwave oven (Daewoo, model TMW-1100EC) for $4 \mathrm{~min} 45 \mathrm{~s}$ at power level '4' while purging with $80 \mathrm{ml}$ $\mathrm{l}^{-1}$ of $\mathrm{N}_{2}$ gas. The collected distillate was cooled in a polystyrene box filled with ice, and the volume was adjusted to $25 \mathrm{ml}$ using Nanopure water. Each $25 \mathrm{ml}$ sample was placed into a $40 \mathrm{ml}$ glass vial containing $6 \mathrm{~g}$ of $\mathrm{NaCl}$. Each vial was sealed with a crimp cap. The vials were stored at $4^{\circ} \mathrm{C}$ until the SPME-GC-MS analysis. Water geosmin content was determined in the same manner. Standard solutions (Supelco) were used to determine the molecular ion base peaks and the retention time. These values were monitored at specific mass to charge ratios $(\mathrm{m} / \mathrm{z})$ 95, 135 and 168 for 2-MIB and at $\mathrm{m} / z$ 112, 126 and 182 for geosmin. The retention time was $11.7 \mathrm{~min}$ for $\mathrm{MIB}$ and $19.7 \mathrm{~min}$ for geosmin. The limit of quantification was $0.001 \mu \mathrm{g} \mathrm{kg}^{-1}$ in fish flesh, whereas the limit of detection by human senses is approximately $0.6 \mu \mathrm{g} \mathrm{kg} \mathrm{kg}^{-1}$ (Cook et al. 2001, Schrader \& Rimando 2003). The human sensory threshold for geosmin in rainbow trout has been placed at $0.1 \mu \mathrm{g} \mathrm{kg}^{-1}$ fish (Petersen et al. 2011). The protocol for detecting geosmin and 2-MIB using GC-MS was previously described by Lloyd \& Grimm (1999) and Auffret et al. (2011).

\section{Water analysis}

Determination of the concentration of inorganic anions and cations was performed on duplicate samples that were derived from the effluent of the fish culture tanks. Water samples $(30 \mathrm{ml})$ were filtered through a $0.45 \mu \mathrm{m}$ filter, and filtrates were analyzed (50 $\mathrm{\mu l}$ volume injection) using ion chromatography (ICS-3000, Dionex). Cations were analyzed with an IonPac AS17 column $(4 \times 250 \mathrm{~mm})$ with a $\mathrm{KOH}$ eluent gradient (9-30 mM, for $16 \mathrm{~min}$ ) with $1 \mathrm{ml} \mathrm{min}{ }^{-1}$ flow rate at $30^{\circ} \mathrm{C}$. Anions were analyzed with an IonPac CS16 column $(5 \times 250 \mathrm{~mm})$ with methanesulfonic acid (42 mM) as eluent with $1 \mathrm{ml} \mathrm{min}^{-1}$ flow rate for $16 \mathrm{~min}$ at $30^{\circ} \mathrm{C}$. Analyses were performed according to methods described in the Appendix. The nitrite samples were analyzed according to the colorimetric method using a HACH DR-2000 spectrophotometer (HACH method 8155: salicylate, and method 8507: diazotization, respectively). Transition metal concentrations were determined using an anion exchange 
chromatography technique (ICS-3000, Dionex). The same analyses were performed according to the method described by Auffret et al. (2013) and furnished in the Appendix.

\section{Statistical analysis}

All data comparing LP and HP diets were subjected to the 2-tailed $t$-test with equal variance. Statistical analyses were carried out using the IBM SPSS program for Windows (v. 20.0). The significance of any apparent differences between mean values was determined at the $95 \%$ level of confidence $(p<0.05)$, unless otherwise stated. Pearson correlation coefficients and the significance of any differences were analyzed for tank water $\mathrm{P}$, water geosmin and fish fillet geosmin data using SPSS.

\section{RESULTS}

Trout reared on the LP diet had very slightly but not significantly greater $(p>$ 0.05 ) final mean biomass gain than those fed the HP diet (Table 2). FCR varied between 1.08 and 1.24. The FCRs for LP replicates were comparable to that of the HP diet. Neither TGC (0.12) nor SGR (0.910.94) was significantly influenced by the dietary treatments throughout the experimental period.

The digestibility of dry matter, protein, lipid and ash varied significantly between the 2 diets (Table 3 ), and were significantly higher $(\mathrm{p}<0.05)$ in fish fed the LP diet $(73.9 \pm 0.4 \%, 91.6 \pm 1.0 \%, 84.4 \pm 0.7 \%$, and $44.6 \pm 0.85 \%$, respectively) compared to fish fed the HP diet $(70.4 \pm 1.2 \%, 85.1 \pm$ $0.4 \%, 78.1 \pm 0.9 \%$ and $37.3 \pm 2.9 \%$ respectively). The digestibility of energy was not significantly influenced by the diets.

The ADC of $\mathrm{P}$ was significantly higher $(p=0.034)$ in fish fed the LP diet compared to fish fed the HP diet. The values for $\mathrm{P}$ retention at the end of the experiment were not significantly different, though $\mathrm{P}$ intake varied widely in the 2 diets (Fig. 1A). Neither nitrogen (except solid) nor energy fractions were influenced by the dietary treatments (Fig. 1B,C). Regarding the concentrations of dissolved and solid P waste, there was a pronounced effect of the dietary P concentrations. Both the dissolved and solid P waste output were significantly higher from fish fed the HP diet $\left(3.0 \pm 0.8\right.$ and $6.0 \pm 0.2 \mathrm{~g} \mathrm{~kg}^{-1}$ fish, respectively) than fish fed the LP diet $\left(0.2 \pm 0.6\right.$ and $2.3 \pm 0.1 \mathrm{~g} \mathrm{~kg}^{-1}$ fish, respectively) (Fig. 1A). Similarly, trout fed the HP diet showed significantly ( $p<0.001)$ higher concentrations of phosphate in tank water for every sampling event until the end of the experiment (Table 4) than fish fed the LP diet. The concentrations of inorganic anions $\left(\mathrm{NO}_{2}{ }^{-}, \mathrm{Cl}^{-}, \mathrm{SO}_{4}{ }^{2-}\right)$ were not significantly different in the tank water of the fish fed the different diets on some sampling events. The cations, e.g. $\mathrm{Fe}^{3+}$ and $\mathrm{Cu}^{2+}$, were not significantly different in the tank water of the fish fed the different diets in all the sampling events throughout the experimental period (Table 5). The cations, e.g. $\mathrm{Na}^{+}$and $\mathrm{Ca}^{2+}$, showed no significant difference in the tank water of the fish fed the different diets on some sampling events. Magnesium $\left(\mathrm{Mg}^{2+}\right)$, potassium $\left(\mathrm{K}^{+}\right)$and zinc $\left(\mathrm{Zn}^{2+}\right)$ concentrations in tank water were significantly lower for fish

Table 2. Mean individual weight (wt) gain, feed conversion ratio (FCR) (see Eq. 2 in 'Materials and methods'), specific growth rate (SGR) (see Eq. 3) and thermal-unit growth coefficient (TGC) (see Eq. 4) for rainbow trout Oncorhynchus mykiss fed low-phosphorus (LP) and high-phosphorus (HP) diet. Survival rate $=$ (Final number of fish/Initial number of fish) $\times 100$. Values are mean \pm SD $(n=4$ tanks per diet $)$. na: not applicable

\begin{tabular}{|c|c|c|c|c|}
\hline \multirow[t]{2}{*}{ Parameter } & \multirow[t]{2}{*}{ Day } & \multicolumn{2}{|c|}{ Treatment } & \multirow[t]{2}{*}{$\mathrm{p}$} \\
\hline & & LP & $\mathrm{HP}$ & \\
\hline \multirow[t]{4}{*}{ Individual wt (g) } & $0-21$ & $159.5 \pm 6.7$ & $159.1 \pm 4.0$ & 0.496 \\
\hline & $21-42$ & $190.0 \pm 6.3$ & $189.9 \pm 2.9$ & 0.618 \\
\hline & $42-63$ & $228.1 \pm 10.0$ & $229.0 \pm 5.4$ & 0.604 \\
\hline & $63-84$ & $275.6 \pm 8.9$ & $277.3 \pm 2.4$ & 0.311 \\
\hline Final mean wt gain $(\mathrm{g})$ & & $146.8 \pm 0.0$ & $151.4 \pm 5.1$ & 0.380 \\
\hline \multirow[t]{4}{*}{ FCR } & $0-21$ & $1.17 \pm 0.03$ & $1.08 \pm 0.18$ & 0.464 \\
\hline & $21-42$ & $1.09 \pm 0.29$ & $1.11 \pm 0.11$ & 0.897 \\
\hline & $42-63$ & $1.15 \pm 0.28$ & $1.21 \pm 0.08$ & 0.748 \\
\hline & $63-84$ & $1.17 \pm 0.00$ & $1.24 \pm 0.00$ & 0.682 \\
\hline Final mean FCR & & $1.14 \pm 0.13$ & $1.15 \pm 0.06$ & 0.480 \\
\hline \multirow[t]{4}{*}{ SGR } & $0-21$ & $1.02 \pm 0.04$ & $1.10 \pm 0.15$ & 0.360 \\
\hline & $21-42$ & $0.78 \pm 0.20$ & $0.74 \pm 0.07$ & 0.688 \\
\hline & $42-63$ & $0.93 \pm 0.80$ & $0.84 \pm 0.06$ & 0.535 \\
\hline & $63-84$ & $0.82 \pm 0.00$ & $0.89 \pm 0.00$ & 0.440 \\
\hline Final mean SGR & & $0.94 \pm 0.00$ & $0.91 \pm 0.02$ & 0.180 \\
\hline \multirow[t]{4}{*}{ TGC } & $0-21$ & $0.11 \pm 0.00$ & $0.13 \pm 0.01$ & 0.383 \\
\hline & $21-42$ & $0.09 \pm 0.02$ & $0.09 \pm 0.01$ & 0.667 \\
\hline & $42-63$ & $0.12 \pm 0.01$ & $0.11 \pm 0.00$ & 0.558 \\
\hline & $63-84$ & $0.11 \pm 0.00$ & $0.16 \pm 0.00$ & 0.417 \\
\hline Final mean TGC & & $0.12 \pm 0.00$ & $0.12 \pm 0.00$ & 0.170 \\
\hline Total feed fed (kg) & & $5.40 \pm 0.00$ & $5.40 \pm 0.00$ & na \\
\hline Survival rate (\%) & & $99.75 \pm 0.50$ & $100.00 \pm 0.00$ & 0.390 \\
\hline
\end{tabular}


Table 3. Apparent digestibility coefficient (ADC) (see Eq. 8 in 'Materials and methods') for dry matter, phosphorus, protein, lipid, energy and ash of rainbow trout Oncorhynchus mykiss fed low-phosphorus (LP) and high-phosphorus (HP) diet. Values are mean \pm SD ( $n=4$ tanks per diet). Significant values $(p<0.05)$ in bold

\begin{tabular}{|lrcr|}
\hline & \multicolumn{2}{c}{ Diet } & \multicolumn{1}{c|}{$\mathrm{p}$} \\
& LP & HP & \\
\hline Dry matter & $73.91 \pm 0.40$ & $70.40 \pm 1.16$ & $<\mathbf{0 . 0 0 1}$ \\
Phosphorus & $59.30 \pm 1.09$ & $53.17 \pm 2.79$ & $\mathbf{0 . 0 3 4}$ \\
Protein & $91.57 \pm 0.96$ & $85.13 \pm 0.43$ & $<\mathbf{0 . 0 0 1}$ \\
Lipid & $84.36 \pm 0.67$ & $78.12 \pm 0.90$ & $\mathbf{0 . 0 1 2}$ \\
Energy & $75.97 \pm 0.48$ & $73.47 \pm 0.30$ & 0.760 \\
Ash & $44.60 \pm 0.85$ & $37.32 \pm 2.92$ & $\mathbf{0 . 0 1 8}$ \\
\hline
\end{tabular}
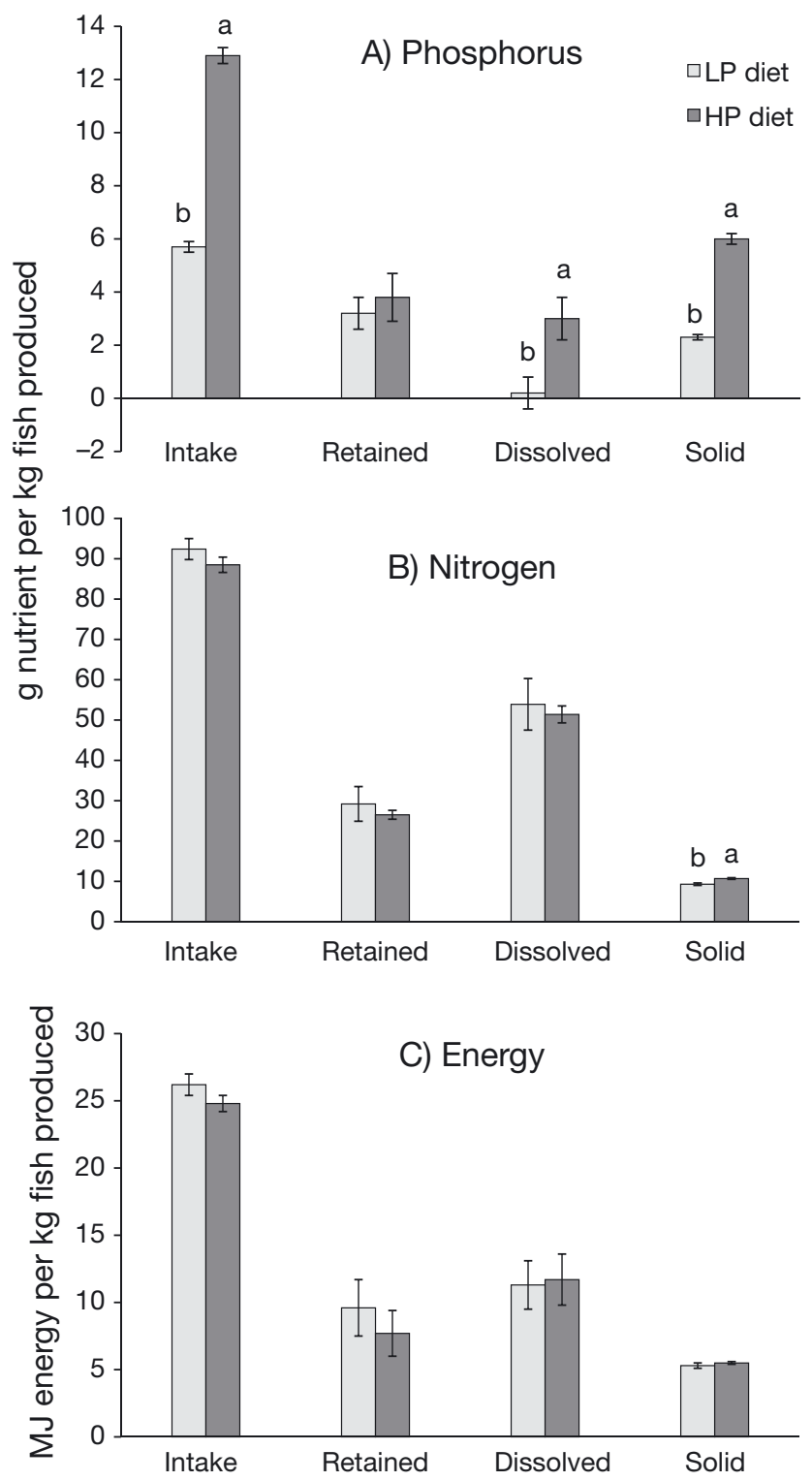

Table 4. Concentration (ppm) of inorganic anions in tank water at each sampling event for rainbow trout Oncorhynchus mykiss fed low-phosphorus (LP) and high-phosphorus (HP) diet. Values are mean \pm SD $(n=4$ tanks per diet). Significant values $(\mathrm{p}<0.05)$ in bold

\begin{tabular}{|c|c|c|c|c|}
\hline \multirow[t]{2}{*}{ Parameter } & \multirow[t]{2}{*}{ Day } & \multicolumn{2}{|c|}{ Treatment } & \multirow[t]{2}{*}{$\mathrm{p}$} \\
\hline & & LP & HP & \\
\hline \multicolumn{5}{|c|}{ Phosphate $\left(\mathrm{PO}_{4}{ }^{3-}\right)$} \\
\hline & 0 & $0.58 \pm 0.10$ & $0.51 \pm 0.01$ & $<0.010$ \\
\hline & 21 & $0.00 \pm 0.00$ & $3.87 \pm 0.02$ & $<0.010$ \\
\hline & 42 & $0.00 \pm 0.00$ & $6.45 \pm 0.10$ & $<0.010$ \\
\hline & 63 & $0.02 \pm 0.00$ & $6.79 \pm 0.18$ & $<0.010$ \\
\hline & 84 & $0.04 \pm 0.00$ & $7.79 \pm 0.06$ & $<0.010$ \\
\hline \multicolumn{5}{|c|}{ Nitrite $\left(\mathrm{NO}_{2}^{-}\right)$} \\
\hline & 0 & $0.05 \pm 0.00$ & $0.03 \pm 0.01$ & 0.136 \\
\hline & 21 & $0.20 \pm 0.00$ & $0.12 \pm 0.00$ & $<0.010$ \\
\hline & 42 & $0.16 \pm 0.00$ & $0.17 \pm 0.00$ & 0.046 \\
\hline & 63 & $0.17 \pm 0.00$ & $0.17 \pm 0.00$ & 0.201 \\
\hline & 84 & $0.16 \pm 0.00$ & $0.17 \pm 0.00$ & 0.018 \\
\hline \multicolumn{5}{|c|}{ Nitrate $\left(\mathrm{NO}_{3}{ }^{-}\right)$} \\
\hline & 0 & $49.06 \pm 0.28$ & $34.69 \pm 0.18$ & $<0.010$ \\
\hline & 21 & $101.28 \pm 3.64$ & $69.94 \pm 1.84$ & $<0.010$ \\
\hline & 42 & $148.70 \pm 4.15$ & $100.04 \pm 1.91$ & $<0.010$ \\
\hline & 63 & $125.70 \pm 10.64$ & $107.17 \pm 3.29$ & 0.036 \\
\hline & 84 & $177.30 \pm 6.55$ & $124.59 \pm 0.79$ & $<0.010$ \\
\hline \multicolumn{5}{|c|}{ Chloride $\left(\mathrm{Cl}^{-}\right)$} \\
\hline & 0 & $44.99 \pm 0.18$ & $39.48 \pm 0.19$ & $<0.010$ \\
\hline & 21 & $39.39 \pm 1.44$ & $39.86 \pm 0.57$ & 0.517 \\
\hline & 42 & $42.33 \pm 1.13$ & $37.59 \pm 0.72$ & 0.014 \\
\hline & 63 & $26.19 \pm 2.22$ & $28.70 \pm 2.78$ & 0.385 \\
\hline & 84 & $24.64 \pm 0.93$ & $23.22 \pm 0.13$ & 0.040 \\
\hline \multicolumn{5}{|c|}{ Sulfate $\left(\mathrm{SO}_{4}{ }^{2-}\right)$} \\
\hline & 0 & $19.93 \pm 0.41$ & $18.51 \pm 0.40$ & 0.011 \\
\hline & 21 & $22.69 \pm 0.87$ & $21.11 \pm 0.84$ & 0.043 \\
\hline & 42 & $29.00 \pm 1.05$ & $24.60 \pm 0.48$ & 0.010 \\
\hline & 63 & $23.22 \pm 2.01$ & $23.38 \pm 0.76$ & 0.880 \\
\hline & 84 & $31.46 \pm 0.90$ & $26.08 \pm 0.23$ & $<0.010$ \\
\hline
\end{tabular}

fed the HP diet than the LP diet for most of the sampling events (Table 5).

The geosmin concentrations of trout fillets were higher in fish fed the HP diet versus the LP diet. A pairwise comparison showed significantly higher geosmin levels in fish fillet with fish fed the HP diet (3.13 $\mathrm{\mu g} \mathrm{kg}^{-1}$ and $2.42 \mu \mathrm{g} \mathrm{kg}^{-1}$ ) than fish fed the LP diet $\left(1.29 \mu \mathrm{g} \mathrm{kg}^{-1}\right.$ and $\left.1.36 \mu \mathrm{g} \mathrm{kg}^{-1}\right)$ for Weeks 3

Fig. 1. Oncorhynchus mykiss. (A) Phosphorus, (B) nitrogen and $(\mathrm{C})$ energy intake, retention and loading estimated at the end of the feeding trial from larger rainbow trout fed lowphosphorus (LP) and high-phosphorus (HP) diet. Mean values ( $\mathrm{n}=4$ tanks per diet) in a column with different superscripts are significantly different $(\mathrm{p}<0.05)$. For calculations of nutrient retention, see Eq. (5) in 'Materials and methods'; solid nutrient load, see Eq. (6); and dissolved nutrient load, see Eq. (7) 
Table 5. Concentration (ppm) of inorganic cations (magnesium, sodium, calcium, potassium) and metals (iron, copper, zinc) in tank water at each sampling event for rainbow trout Oncorhynchus mykiss fed low-phosphorus (LP) and highphosphorus (HP) diet. Values are mean $\pm \mathrm{SD}(\mathrm{n}=4$ tanks per diet). Significant values $(p<0.05)$ in bold

\begin{tabular}{|c|c|c|c|c|}
\hline \multirow[t]{2}{*}{ Parameter } & \multirow[t]{2}{*}{ Day } & \multicolumn{2}{|c|}{ Treatment } & \multirow[t]{2}{*}{$\mathrm{p}$} \\
\hline & & LP & HP & \\
\hline \multicolumn{5}{|c|}{ Magnesium $\left(\mathrm{Mg}^{2+}\right)$} \\
\hline & 0 & $2.60 \pm 0.03$ & $2.48 \pm 0.03$ & 0.040 \\
\hline & 21 & $3.22 \pm 0.02$ & $2.95 \pm 0.00$ & $<0.010$ \\
\hline & 42 & $2.42 \pm 0.09$ & $2.42 \pm 0.03$ & 0.972 \\
\hline & 63 & $2.18 \pm 0.03$ & $2.09 \pm 0.02$ & 0.046 \\
\hline & 84 & $2.31 \pm 0.04$ & $2.14 \pm 0.03$ & 0.020 \\
\hline \multicolumn{5}{|c|}{ Sodium $\left(\mathrm{Na}^{+}\right)$} \\
\hline & 0 & $52.00 \pm 0.84$ & $45.46 \pm 1.17$ & 0.004 \\
\hline & 21 & $70.12 \pm 4.90$ & $52.58 \pm 17.76$ & 0.194 \\
\hline & 42 & $104.25 \pm 3.60$ & $92.39 \pm 1.90$ & 0.017 \\
\hline & 63 & $75.54 \pm 5.86$ & $80.84 \pm 2.55$ & 0.140 \\
\hline & 84 & $95.88 \pm 5.31$ & $77.29 \pm 0.72$ & $<0.010$ \\
\hline \multicolumn{5}{|c|}{ Calcium $\left(\mathrm{Ca}^{2+}\right)$} \\
\hline & 0 & $24.32 \pm 0.28$ & $22.27 \pm 0.39$ & 0.006 \\
\hline & 21 & $17.04 \pm 0.08$ & $16.67 \pm 0.16$ & 0.038 \\
\hline & 42 & $14.24 \pm 0.24$ & $14.81 \pm 0.17$ & 0.072 \\
\hline & 63 & $12.65 \pm 0.21$ & $13.60 \pm 0.13$ & $<0.010$ \\
\hline & 84 & $11.77 \pm 0.27$ & $13.61 \pm 0.16$ & $<0.010$ \\
\hline \multicolumn{5}{|c|}{ Potassium $\left(\mathrm{K}^{+}\right)$} \\
\hline & 0 & $1.97 \pm 0.01$ & $1.76 \pm 0.01$ & 0.024 \\
\hline & 21 & $2.05 \pm 0.00$ & $1.67 \pm 0.02$ & $<0.010$ \\
\hline & 42 & $2.32 \pm 0.00$ & $1.81 \pm 0.10$ & $<0.010$ \\
\hline & 63 & $2.24 \pm 0.00$ & $1.93 \pm 0.18$ & $<0.010$ \\
\hline & 84 & $3.09 \pm 0.00$ & $2.53 \pm 0.06$ & $<0.010$ \\
\hline \multicolumn{5}{|l|}{ Iron $\left(\mathrm{Fe}^{3+}\right)$} \\
\hline & 0 & $0.62 \pm 0.78$ & $0.02 \pm 0.04$ & 0.221 \\
\hline & 21 & $2.95 \pm 0.77$ & $2.95 \pm 0.82$ & 0.180 \\
\hline & 42 & $2.35 \pm 0.74$ & $2.35 \pm 0.00$ & 0.320 \\
\hline & 63 & $2.42 \pm 0.34$ & $2.42 \pm 2.03$ & 0.393 \\
\hline & 84 & $2.78 \pm 0.70$ & $2.78 \pm 1.41$ & 0.090 \\
\hline \multicolumn{5}{|c|}{ Copper $\left(\mathrm{Cu}^{2+}\right)$} \\
\hline & 0 & $1.03 \pm 0.44$ & $1.31 \pm 1.04$ & 0.639 \\
\hline & 21 & $1.46 \pm 0.42$ & $1.35 \pm 0.19$ & 0.473 \\
\hline & 42 & $1.49 \pm 0.48$ & $0.94 \pm 0.42$ & 0.434 \\
\hline & 63 & $1.05 \pm 0.21$ & $1.05 \pm 0.42$ & 0.594 \\
\hline & 84 & $1.35 \pm 0.54$ & $0.62 \pm 0.33$ & 0.117 \\
\hline \multicolumn{5}{|l|}{$\operatorname{Zinc}\left(\mathrm{Zn}^{2+}\right)$} \\
\hline & 0 & $5.38 \pm 0.29$ & $4.37 \pm 1.26$ & 0.402 \\
\hline & 21 & $6.83 \pm 1.35$ & $4.44 \pm 0.50$ & 0.051 \\
\hline & 42 & $6.35 \pm 0.52$ & $3.65 \pm 0.58$ & 0.001 \\
\hline & 63 & $6.38 \pm 0.59$ & $4.73 \pm 0.74$ & 0.017 \\
\hline & 84 & $10.77 \pm 2.30$ & $7.02 \pm 0.44$ & 0.048 \\
\hline
\end{tabular}

(Day 21) and 6 (Day 42), respectively (Fig. 2). However, there was no significant difference detected between the 2 diets at the Week 8 (Day 56) and Week 12 (Day 84) sampling events, although considerable variability in concentrations was observed. Geosmin concentrations of the tank water, biofilter

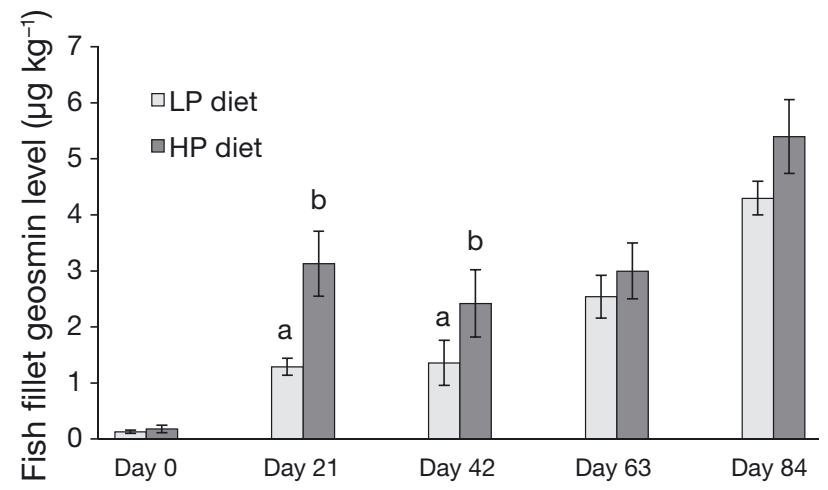

Fig. 2. Oncorhynchus mykiss. Concentration of geosmin in rainbow trout flesh fed low-phosphorus (LP) and highphosphorus (HP) diet for $84 \mathrm{~d}$. Data are means $( \pm \mathrm{SD})$ of 4 tanks ( 3 fish per tank) per diet. Different letters above bars indicate significant difference at $\mathrm{p}<0.05$
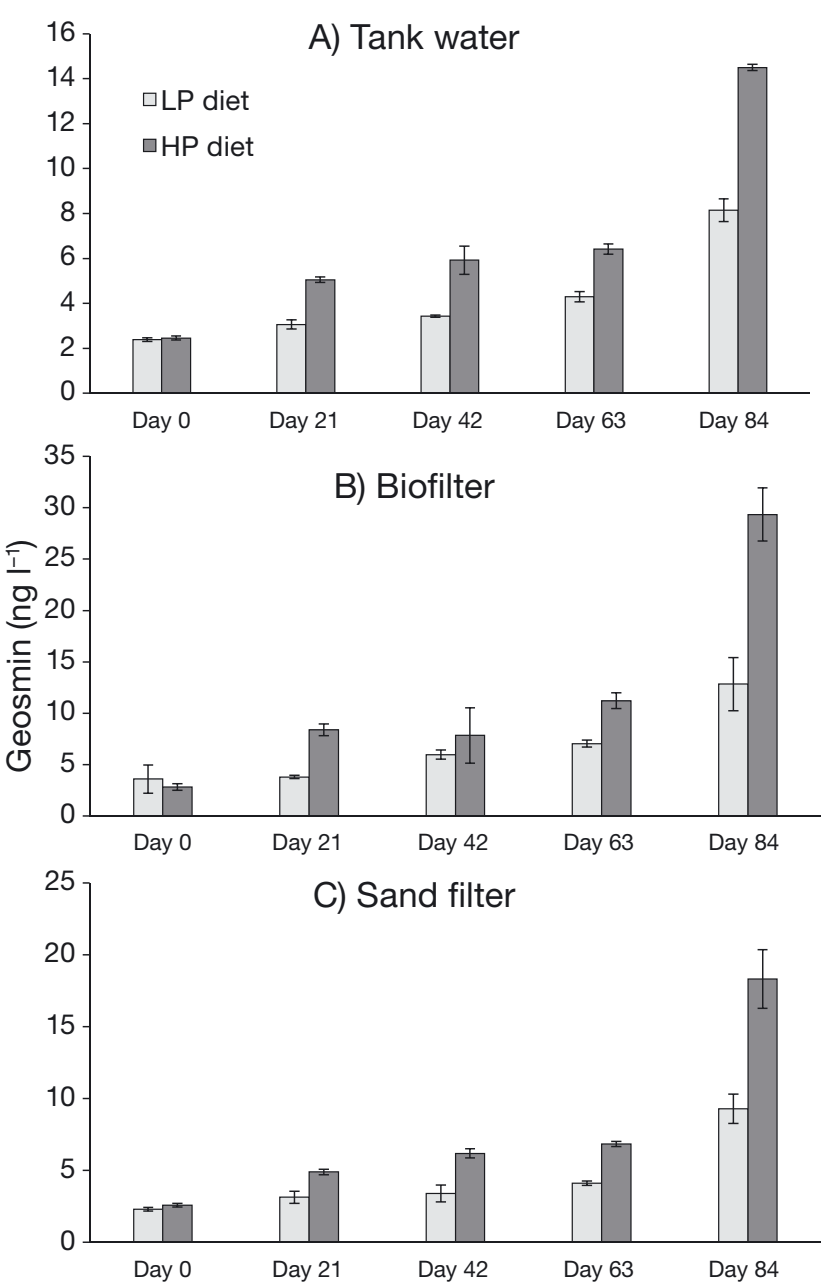

Fig. 3. Oncorhynchus mykiss. Changes in geosmin concentration in the (A) tank water, (B) biofilter and (C) sand filter of the tanks where fish received low-phosphorus (LP) and high-phosphorus (HP) diet for $84 \mathrm{~d}$. Data are means $( \pm \mathrm{SD})$ of 4 tanks per diet 

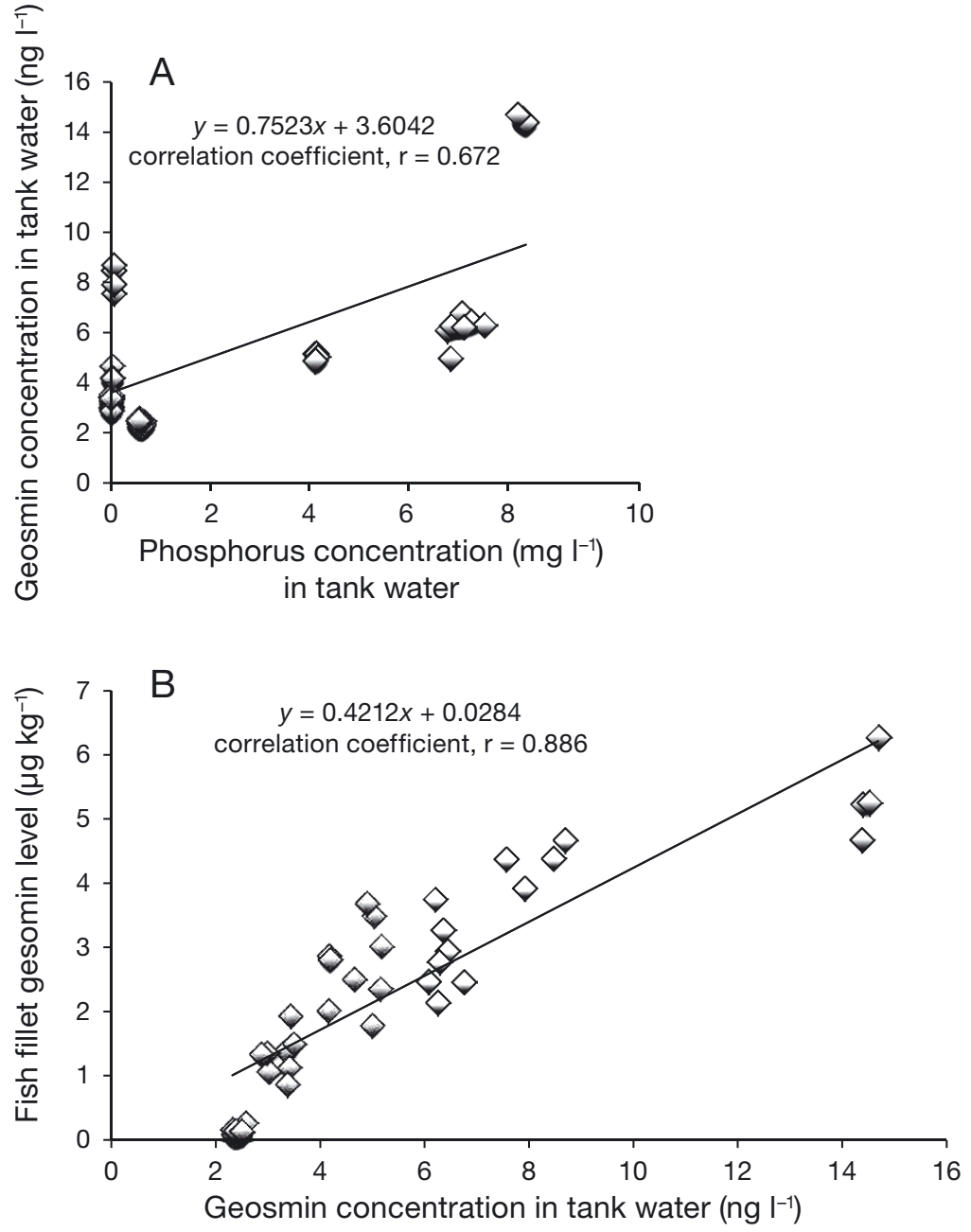

Fig. 4. Oncorhynchus mykiss. Linear correlations between (A) the phosphorus and geosmin concentrations in tank water and (B) the geosmin concentration in tank water and that in fish fillets from the feeding trial where fish received low-phosphorus (LP) and highphosphorus (HP) diet. Data are means $( \pm \mathrm{SD})$ of 4 tanks per diet. Correlations are significant at $\mathrm{p}<0.0001$

and sand filter were higher for the fish that received the HP diet versus the LP diet in all sampling events; however, the difference was not significant between the 2 diets (Fig. 3A-C). Although there was no strong linear relationship between soluble $\mathrm{P}$ concentration and geosmin in tank water when we integrated the data from both the LP and the HP diets $(y=0.7523 x+3.6042 ; \mathrm{r}=0.672 ; \mathrm{p}<0.0001)$ (Fig. 4A), the relationship was stronger in the HP diet (data not shown). Furthermore, there was a strong proportional linear relationship between the geosmin concentration in tank water and geosmin concentration in fish fillet of the fish fed the LP diet and HP diet $(y=0.4212 x+0.0284 ; \mathrm{r}=0.886 ; \mathrm{p}<$ 0.0001) (Fig. 4B).

\section{DISCUSSION}

The reduction of $\mathrm{P}$ waste output from aquaculture operations is considered a key element for the long-term sustainability of aquaculture. The most direct method of reducing P loading is achieved by manipulation of the P concentration in feed and improvement of diet digestibility. Current commercial trout feeds usually have a total $\mathrm{P}$ content that varies from 10 to $14.3 \mathrm{~g} \mathrm{~kg}^{-1}$ diet (Sarker et al. 2011). As expected, the total $\mathrm{P}$ content of the HP diet (13 $\mathrm{g} \mathrm{kg}^{-1}$ diet) in this study resembles the $\mathrm{P}$ content of commercial trout diets. The TGC and FCR values did not vary between the 2 diets; that the FCR values were identical throughout the study indicates that the protein and energy content of the diets were balanced (Cho \& Kaushik 1990). In the present study, growth was not affected by the LP diet when compared to the HP diet. The growth performance of fish in the current study confirmed that the LP (5.4 $\mathrm{g} \mathrm{kg}^{-1}$ diet) diet had sufficient total $\mathrm{P}$ to satisfy the minimum requirement for large rainbow trout. In large fish, the focus of the present study, the requirement for $\mathrm{P}$ is known to decrease with age because the growth rate decreases and dietary $\mathrm{P}$ is used mainly for maintaining metabolic functions (Lellis et al. 2004, Koko et al. 2010). The P content of the LP diet was in the range of the dietary $\mathrm{P}$ requirement that has been reported for normal growth of rainbow trout, 4.0-6.0 g $\mathrm{kg}^{-1}$ (Ketola \& Richmond 1994, Rodehutscord 1996). Similar findings suggest that available $P$ levels can be reduced in rainbow trout diets to $4.7 \mathrm{~g} \mathrm{~kg}^{-1}$ diet at $314 \mathrm{~g}$ live mass without loss in production (Rodehutscord 1996).

Fish fed the LP diet were characterized by very low dissolved and solid waste P output, suggesting that this diet approached maximum retention and the $P$ requirement was met. Non-fecal P (urinary or gill) concentration has been shown to be a rapid and sensitive indicator of dietary P intake (Bureau \& Cho 1999, Sugiura et al. 2000). Research has shown that non-fecal $P$ (urinary or gill excretion) is significantly lower in fish fed an LP diet compared to an HP diet (Sugiura et al. 2000). In the present study, the amount of retained $P$ by fish in the LP and HP dietary groups were not significantly different (Fig. 1A), which reflects that the physiological P needs of both dietary groups were met.

It is well known that vertebral deformities may appear long before any growth reduction is exhibited. 
In juvenile Atlantic salmon Salmo salar and rainbow trout, it has been observed that continual feeding on a P-deficient diet eventually leads to poor bone mineralization and deformities (Vielma \& Lall 1998, Fontagnè et al. 2009, Fjelldal et al. 2012). This phenomenon has also been observed in large fish. For instance, Koko et al. (2010) found that changes in weight of $164 \mathrm{~g}$ trout fed deficient $\mathrm{P}\left(4.0 \mathrm{~g} \mathrm{~kg}^{-1}\right.$ diet $)$ and sufficient $\mathrm{P}$ (8.0 $\mathrm{g} \mathrm{kg}^{-1}$ diet) over time remained similar during the initial $56 \mathrm{~d}$. After this period, poor growth performance and a number of visual deficiency signs were observed, such as bone deformities in the tail regions of trout fed the P-deficient diet. However, there were no visual signs of P deficiency in the current study. This indicates that fish fed the LP diet received an adequate level of $\mathrm{P}$ for bone mineralization for the $84 \mathrm{~d}$ feeding period. However, more work is required on the effect of an LP diet on rainbow trout health and bone mineralization in a longer-term feeding trial, which our research team is currently investigating.

Even though the diets were both isocaloric and isonitrogenous, there was a significant depression in the apparent digestibility of dry matter, $\mathrm{P}$, ash, protein and lipid of fish fed the HP diet (containing $6.9 \mathrm{~g}$ digestible $\mathrm{P} \mathrm{kg}{ }^{-1}$ diet). There was also a substantial increase in the $\mathrm{P}$ waste output fractions, which could suggest that these fish were somehow negatively affected by the high $\mathrm{P}$ intake. Based on the results of $P$ budgets, fish in all dietary treatment groups dis-

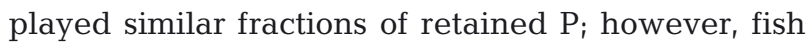
in the HP dietary treatment groups excreted a comparatively significant higher amount $\left(6 \mathrm{~g} \mathrm{P} \mathrm{kg}^{-1}\right.$ fish produced) of solid P. Non-fecal dissolved P excretion occurs only when the diet contains available/ digestible $\mathrm{P}$ that exceeds the requirement level (Bureau \& Cho 1999, Rodehutscord et al. 2000, Sugiura et al. 2000, Sarker et al. 2009). In the present study, the dissolved $\mathrm{P}$ waste output was very minimal (0.2 $\mathrm{g} \mathrm{P} \mathrm{kg}^{-1}$ fish produced) from fish fed the LP diet (3.2 $\mathrm{g}$ digestible $\mathrm{P} \mathrm{kg}{ }^{-1}$ ), increasing (3 $\mathrm{g} \mathrm{P} \mathrm{kg}^{-1}$ fish produced) significantly in the fish fed the HP diet (6.9 $\mathrm{g}$ digestible $\mathrm{P} \mathrm{kg}^{-1}$ diet), suggesting that the dietary $\mathrm{P}$ requirement had been exceeded in this group. The fact that the fish fed the LP diet displayed significantly lower or borderline (negative value) dissolved $\mathrm{P}$ waste output presumably reflects that the fish were P-limited at the start of the trial $\left(0 \mathrm{mg} \mathrm{P} \mathrm{l}^{-1}\right.$ in tank water for Days 21 and 42), therefore retaining a larger share of dietary P (Sugiura et al. 2000).

The current study seeks to clarify the impact of dietary $\mathrm{P}$ concentration and the magnitude of the waste $\mathrm{P}$ production on the appearance of off-flavor compound deposition in fish flesh and water. The $\mathrm{P}$ budgets balanced very well, verifying that the fate of dietary P had been satisfyingly accounted for. Fish fed the HP diet displayed higher geosmin concentrations in fillets throughout the experimental period, and the difference with the LP group was significant until Day 42. In the LP group, the fish fillet geosmin level was very low at Day 0 compared to Day 84, whereas the phosphate level in water was quite high at Day 0 (0.58 ppm) compared to Day 84 (0.04 ppm). This could be attributed to the fact that the fish were P-limited at the start of the trial, and fish receiving the LP diet displayed a net disappearance of soluble $\mathrm{P}$ concentration $\left(0 \mathrm{mg} \mathrm{l}^{-1}\right)$ from the tank water (Table 4). They may have retained maximum P until Day 42 for their physiological requirement or could even have taken up soluble P from water via gills (Sugiura et al. 2003, Sarker et al. 2011). This disappearance of soluble $\mathrm{P}$ in the water indicated that $\mathrm{P}$ might not be stimulating the growth or proliferation of microorganisms, and coincided with the lower concentration of the geosmin level for the first $42 \mathrm{~d}$ in fish fed the LP diet (Findlay et al. 2009, Auffret et al. 2011). However, it should be noted that the concentration of geosmin levels in fish was high, $>2.4 \mu \mathrm{g}$ $\mathrm{kg}^{-1}$ fish for both diets. The human sensory threshold for geosmin in rainbow trout ranges from 0.1 to $0.9 \mu \mathrm{g}$ $\mathrm{kg}^{-1}$ fish (Robertson et al. 2005, Peterson et al. 2011). This suggests that even though fish fed the LP diet contributed less geosmin concentration in fillet, further reduction is needed to achieve a level below the sensory threshold. To provide adequate conditions for depuration of off-flavors, either the fish could be moved to clean odor-free water or the geosmin could be removed from the culture water in situ (Robertson et al. 2005, Burr et al. 2012); e.g. rainbow trout depuration periods of $\sim 1$ wk are typically practiced (Petersen et al. 2011, 2014).

This study demonstrated that the concentration of geosmin in the rainbow trout flesh is highly correlated with the accumulated geosmin concentration in the tank water. The accumulation of tainting compounds in flesh is extremely rapid (Robertson et al. 2005) and can be intensified by the lipid content of fish (Johnsen \& Lloyd 1992, Jones et al. 2013). The higher geosmin levels in the fish on Days 63 and 84 relative to Day 42 might be linked with the body lipid content of fish. Although we did not determine the relationship between lipid content of fish flesh and uptake of geosmin concentration in this study, our previous study confirmed the fact that the concentration of lipid in trout has an influence on the uptake of geosmin in water (authors' unpubl.). This suggests that due to the relationship 
between geosmin uptake and lipid content, the lean fish could contribute potentially the lower concentration of taint compounds in farmed fish (Johnsen \& Lloyd 1992, Robertson et al. 2005).

The aquafeeds industry has long recognized and driven research to find aquafeeds that use alternative protein ingredients, particularly plant-derived proteins (Gatlin et al. 2007). Plant-derived proteins contain high levels of phytate-bound P (Mainstone \& Parr 2002, Sarker et al. 2006, 2013), which is largely (70\%) indigestible to monogastric animals like fish, who lack endogenous phytase activity to liberate phytate P (NRC 1993). Thus, P ends up in fish culture effluents, which contribute to eutrophication (Mainstone \& Parr 2002, Sarker et al. 2009). P balance calculations indicated that both solid and dissolved $\mathrm{P}$ production was higher in the HP diet than LP diets, therefore confirming that a difference in digestibility between diets was due to the difference in supplemented $\mathrm{P}$ concentration in the diet, not the level of phytate $\mathrm{P}$, which was the same in both diets. Use of phytase enzymes to increase utilization of phytate $\mathrm{P}$ in the feed may be beneficial in reducing the growth of microorganisms and thus reducing the occurrence of off-flavor. However, this experiment was not designed to study the dietary P source (such as phytate) in relationship to off-flavor. Moreover, the influence of microbial activity on the phosphate concentration in water was not directly evaluated in this study. Thus, more research is certainly needed to explore the effects/consequences of phytate $\mathrm{P}$ with respect to $\mathrm{P}$ waste outputs and geosmin-associated off-flavor compounds in fish raised in RAS.

Regardless of this mechanism, it is important to note that low concentrations of P in RAS may contribute to lowering geosmin-associated off-flavor in the culture system and in fillet from fish raised in RAS. The large increase of geosmin concentration reflects the $\mathrm{P}$ waste output in the system water that facilitated the proliferation of microorganisms (Auffret et al. 2011). The effectiveness of $\mathrm{P}$ utilization by microorganisms is stimulated by the fraction of the $\mathrm{P}$ loading from fish culture operation that is biologically available (Findlay et al. 2009). This is due to the fact that most of the dissolved $\mathrm{P}$ waste excreted by the fish is in the form of orthophosphate (Bureau \& Cho 1999), a component that is readily available to the microorganisms. Likewise, Redfield (1958) and Armstrong (1999) reported that available $\mathrm{P}$ in water is one of the key factors implicated in cyanobacterial proliferation and contributes to producing geosmin-associated off-flavor compounds in the aquaculture system (Ridal et al. 1999, Sugiura \& Nakano 2000, Dzialowski et al. 2009).
It has been reported that the P released from sediment induces off-flavor problems in catfish and carp ponds when the $\mathrm{P}$ content in the water was in the range of 0.33-0.71 $\mathrm{mg}^{-1}$ (Zimba et al. 2003, Vallod et al. 2007). An amount of $1 \mathrm{mg} \mathrm{l}^{-1}$ was previously correlated with the occurrence of geosmin production in aquaculture systems (Robertson et al. 2006). This amount has also been shown to control the biosynthesis of secondary metabolites such as geosmin in Streptomyces sp. (Schrader \& Blevins 2001, Martín 2004). A number of microorganisms can produce volatile organic compounds that affect the taste and smell of fish and water; e.g. several taxa of cyanobacteria (blue-green algae), filamentous Actinobacteria (actinomycetes) and Myxobacteria frequently produce 2 key off-flavor compounds, geosmin and 2-MIB, in aquaculture and other aquatic environments (Tucker \& Martin 1991, Jüttner \& Watson 2007, Auffret et al. 2011). However, in indoor RAS tank conditions, cyanobacteria might not grow as favorably as in open water ponds due to the presence of sunlight outdoors. In indoor trout tanks, the growth of non-photosynthetic microbes could be a major source of geosmin. In this study, changes in geosmin concentration in tank water, biofilter and sand filter increased over time until the end of the experiment; at every sampling event, fish receiving the HP diet showed numerically (not statistically) higher concentrations of geosmin. In this study, Pearson correlation analysis was performed and showed that the soluble P concentration in tank water was not strongly correlated (correlation coefficient, $\mathrm{r}=0.672$; $\mathrm{p}<0.0001$ ) with the geosmin concentration when we integrated all the data from the 2 dietary treatments; however, the relationship is even stronger (correlation coefficient, $r=0.769$; $p<0.0001$ ) when considering only fish receiving the HP diet (data not shown).

It is important to note that RAS biofilms can be a major source of the off-flavor compounds. It has been reported that in RAS, the biofilter and the sand filter are the 2 compartments that are known to concentrate geosmin producers and to accumulate phosphate (Shnel et al. 2002, Guttman \& van Rijn 2008). In our previous study, we reported that the detected Streptomyces, Myxococcales, Sorangium and Nannocystis coincided with the detection of geosmin in trout raised in RAS (Auffret et al. 2011, 2013), and there was a positive correlation between Nannocystis in the fish tank and the detection of geosmin in fish tissue. Auffret et al. (2013) also speculated that P could be associated with the abundance of Sorangium and the geosmin-synthesis gene that could enhance the geosmin production in RAS. 
In all sampling events of the present study, 2-MIB was recorded below detectable levels, suggesting that it had a negligible influence on earthy taint episodes in rainbow trout flesh and the water in which they were raised. To our knowledge, there are no published studies addressing the influence of dietary P on the development of off-flavor (geosmin) in trout fillet and system water. The results from this study suggest that care should be taken in the formulation of diets with high $\mathrm{P}$ levels that exceed the requirement levels for large fish, without considering metabolic waste outputs into the environment and the obvious risk of producing off-flavor compounds in water and fish flesh.

Several micronutrients, e.g. inorganic cations $\mathrm{Na}^{+}$, $\left.\mathrm{Ca}^{2+}, \mathrm{Fe}^{3+}, \mathrm{Cu}^{2+}\right)$ in the tank water of fish fed both diets tested in this study were not significantly different. These micronutrients have not been identified as having considerable influence on the yield of several bacterial metabolites like geosmin. It has been previously reported that $\mathrm{Ca}^{2+}, \mathrm{K}^{+}$and $\mathrm{Cu}^{2+}$ usually do not affect the secondary metabolism of bacteria and geosmin production (Schrader \& Blevins 2001). However, significantly lower concentration of zinc in the tank water of fish fed the HP diet could stimulate the secondary metabolism of bacteria and permit greater geosmin production, as has been reported previously (Weinberg 1989). In the case of inorganic anions, with the exception of $\mathrm{PO}_{4}{ }^{3-}$ concentration (significantly higher), some other anions such as $\left(\mathrm{NO}_{2}{ }^{-}, \mathrm{Cl}^{-}, \mathrm{SO}_{4}{ }^{2-}\right)$ were not found significantly different in the tank water of fish fed both the HP and LP diets on some sampling events. The impact of differing levels of these micronutrients in water is not well understood. Therefore, in the current study, it is unclear how metabolic $\mathrm{P}$ waste in water could interact with other environmental parameters and regulate the synthesis of geosmin in water and fish tissue, so further research is needed to elucidate this.

\section{CONCLUSION AND IMPLICATIONS}

The results of this study suggest that off-flavor compounds in water and fish fillets raised in RAS were related to the $\mathrm{P}$ concentration in the diet and consequent metabolic $\mathrm{P}$ waste output into the system. This study provides evidence that nutritional strategies and utilization of low-P feed in larger rainbow trout lead to significant reduction of $\mathrm{P}$ waste outputs and an off-flavor compound (geosmin) in RAS systems and consequentially in fillets without compromising fish growth and productivity.
Acknowledgements. We express our appreciation to the Natural Sciences and Engineering Research Council (NSERC) of Canada, the Réseau Aquaculture Québec (RAQ) (Rimouski, QC) and the Société de recherche et de développement en aquaculture continentale Inc. for financial support. We thank the staff of the Laboratoire Régional des Sciences Aquatiques (LARSA, Université Laval, QC, Canada) for their facilities and for technical assistance.

\section{LITERATURE CITED}

AOAC (Association of Official Analytical Chemists) (1990) Method numbers 927.05 and 930.30. In: Official methods of analysis, 15th edn. AOAC, Washington, DC

Armstrong RA (1999) An optimization-based model of iron-lightammonium co-limitation of nitrate uptake and phytoplankton growth. Limnol Oceanogr 44:1436-1446

Auffret M, Pilote A, Proulx E, Proulx D, Vandenberg G, Villemur R (2011) Establishment of a real-time PCR method for quantification of geosmin-producing Streptomyces spp. in recirculating aquaculture systems. Water Res 45:6753-6762

Auffret M, Yergeau É, Pilote A, Proulx É and others (2013) Impact of water quality on the bacterial populations and off-flavours in recirculating aquaculture systems. FEMS Microbiol Ecol 84:235-247

> Bai Z, Pilote A, Sarker PK, Vandenberg G, Pawliszyn J (2013) In-vivo solid phase microextraction with ex-vivo calibration: determination of off flavor components in live fish. Anal Chem 85:2328-2332

Bureau DP, Cho CY (1999) Phosphorus utilization by rainbow trout (Oncorhynchus mykiss): estimation of dissolved phosphorus waste output. Aquaculture 179:127-140

Burr GS, Wolters WR, Schrader KK, Summerfelt ST (2012) Impact of depuration of earthy-musty off-flavors on fillet quality of Atlantic salmon, Salmo salar, cultured in a recirculating aquaculture system. Aquacult Eng 50: 28-36

Camargo JA, Alonso Á (2006) Ecological and toxicological effects of inorganic nitrogen pollution in aquatic ecosystems: a global assessment. Environ Int 32:831-849

CCAC (Canadian Council on Animal Care) (1984) Guide to the care and use of experimental animals, Vol 2. CCAC, Ottawa

Cho CY, Kaushik SJ (1990) Nutritional energy in fish: energy and protein utilization in rainbow trout (Salmo gairdneri). World Rev Nutr Diet 61:132-172

Cho CY, Slinger SJ (1979) Apparent digestibility measurement in feedstuffs for rainbow trout (Salmo gairdneri). Proc World Symp Finfish Nutrition and Fish feed Technology, 20-23 June 1978, Hamburg, Vol 2. Heenemann, Berlin, p 239-247

Cho CY, Slinger SJ, Bayley HS (1982) Bioenergetics of salmonid fishes: energy intake, expenditure and productivity. Comp Biochem Physiol B 73:25-41

Cook D, Newcombe G, Sztajnbok P (2001) The application of powdered activated carbon for MIB and geosmin removal: predicting PAC doses in four raw waters. Water Res 35:1325-1333

CPAUL (Animal Protection Committee of Université Laval) (2010) Politique concernant l'utilisation des animaux en recherche, en enseignement et dans les tests, CA-201086. Université Laval, Québec

> Downing JA, Watson SB, McCauley E (2001) Predicting 
cyanobacteria dominance in lakes. Can J Fish Aquat Sci 58:1905-1908

- Dzialowski AR, Smith VH, Huggins DG, deNoyelles F, Lim N, Baker DS, Beury JH (2009) Development of predictive models for geosmin-related taste and odor in Kansas, USA, drinking water reservoirs. Water Res 43:2829-2840

Findlay DL, Podemski CL, Kasian SEM (2009) Aquaculture impacts on the microbial communities in a small boreal forest lake. Can J Fish Aquat Sci 66:1936-1948

> Fjelldal PG, Hansen T, Albrektsen S (2012) Inadequate phosphorus nutrition in juvenile Atlantic salmon has a negative effect on long-term bone health. Aquaculture 334-337:117-123

Fontagnè S, Silva N, Bazin D, Ramos A and others (2009) Effects of dietary phosphorus and calcium level on growth and skeletal development in rainbow trout (Oncorhynchus mykiss) fry. Aquaculture 297:141-150

> Gatlin DM III, Barrows FT, Brown P, Dabrowski K and others (2007) Expanding the utilization of sustainable plant products in aquafeeds: a review. Aquacult Res 38: 551-579

> Gerber NN (1969) A volatile metabolite of actinomycetes, 2methylisoborneol. J Antibiot 22:508-509

Grimm CC, Lloyd SW, Batista R, Zimba PV (2000) Using microwave distillation-solid-phase microextraction-gas chromatography-mass spectrometry for analyzing fish tissue. J Chromatogr Sci 38:289-296

> Guttman L, van Rijn J (2008) Identification of conditions underlying production of geosmin and 2-methylisoborneol in a recirculating system. Aquaculture 279:85-91

> Houle S, Schrader KK, François NRL, Comeau Y and others (2011) Geosmin causes off-flavour in arctic charr in recirculating aquaculture systems. Aquacult Res 42:360-365

> Johnsen PB, Lloyd SW (1992) Influence of fat content on uptake and depuration of the off-flavor 2-methylisoborneol by channel catfish (Ictalurus punctatus). Can J Fish Aquat Sci 49:2406-2411

> Jones B, Fuller S, Carton AG (2013) Earthy-muddy tainting of cultured barramundi linked to geosmin in tropical northern Australia. Aquacult Environ Interact 3:117-124

> Jüttner F, Watson SB (2007) Biochemical and ecological control of geosmin and 2-methylisoborneol in source waters. Appl Environ Microbiol 73:4395-4406

Ketola HG, Richmond ME (1994) Requirement of rainbow trout for dietary phosphorus and its relationship to the amount discharged in hatchery effluents. Trans Am Fish Soc 123:587-594

Keulen JV, Young BA (1977) Evaluation of acid-insoluble ash as a natural marker in ruminant digestibility studies. J Anim Sci 44:282-287

> Koko GKD, Sarker PK, Proulx E, Vandenberg GW (2010) Effects of alternating feeding regimes with varying dietary phosphorus levels on growth, mineralization, phosphorus retention and loading of large rainbow trout (Oncorhynchus mykiss). Aquat Living Resour 23: 277-284

Lall SP (1991) Digestibility, metabolism and excretion of dietary phosphorus in fish. In: Chowey CB, Cho CY (eds) Nutritional strategies and aquaculture waste. Proc 1st Int Symp Nutritional Strategies in Management of Aquaculture Waste. University of Guelph, Guelph, p 21-36

Lellis WA, Barrows FT, Hardy RW (2004) Effects of phasefeeding dietary phosphorus on survival, growth, and processing characteristics of rainbow trout Oncorhynchus mykiss. Aquaculture 242:607-616
Lloyd SW, Grimm CC (1999) Analysis of 2-methylisoborneol and geosmin in catfish by microwave distillation-solidphase microextraction. J Agric Food Chem 47:164-169

Mainstone CP, Parr W (2002) Phosphorus in rivers - ecology and management. Sci Total Environ 282-283:25-47

Martín JF (2004) Phosphate control of the biosynthesis of antibiotics and other secondary metabolites is mediated by the PhoR-PhoP system: an unfinished story. J Bacteriol 186:5197-5201

NRC (National Research Council) (1993) Nutrient requirements of fish. National Academy Press, Washington, DC

> Petersen MA, Hyldig G, Strobel BW, Henriksen NH, Jørgensen NOG (2011) Chemical and sensory quantification of geosmin and 2-methylisoborneol in rainbow trout (Oncorhynchus mykiss) from recirculated aquacultures in relation to concentrations in basin water. J Agric Food Chem 59:12561-12568

> Petersen MA, Alam MD, Rahman MM, Ali ML, Mahmud S, Schlüter L, Jørgensen NOG (2014) Geosmin off-flavour in pond-raised fish in southern Bangladesh and occurrence of potential off-flavour producing organisms. Aquacult Environ Interact 5:107-116

Redfield AC (1958) The biological control of the chemical factors in the environment. Am Sci 46:205-221

Ridal JJ, Brownlee B, Lean DRS (1999) Occurrence of the odor compounds, 2-methylisoborneol and geosmin in eastern Lake Ontario and the upper St. Lawrence River. J Gt Lakes Res 25:198-204

Robertson RF, Jauncey K, Beveridge MCM, Lawton LA (2005) Depuration rates and the sensory threshold concentration of geosmin responsible for earthy-musty taint in rainbow trout, Onchorhynchus mykiss. Aquaculture 245:89-99

Robertson RF, Hammond A, Jauncey K, Beveridge MCM, Lawton LA (2006) An investigation into the occurrence of geosmin responsible for earthy-musty taints in UK farmed rainbow trout, Onchorhynchus mykiss. Aquaculture 259:153-163

Robin J, Cravedi JP, Hillenweck A, Deshayes C, Vallod D (2006) Off flavor characterization and origin in French trout farming. Aquaculture 260:128-138

Rodehutscord M (1996) Response of rainbow trout (Oncorhynchus mykiss) growing from 50 to $200 \mathrm{~g}$ to supplements of dibasic sodium phosphate in a semipurified diet. J Nutr 126:324-331

> Rodehutscord M, Gregus Z, Pfeffer E (2000) Effect of phosphorus intake on faecal and non-faecal phosphorus excretion in rainbow trout (Oncorhynchus mykiss) and the consequences for comparative phosphorus availability studies. Aquaculture 188:383-398

Saadoun IMK, Schrader KK, Blevins WT (2001) Environmental and nutritional factors affecting geosmin synthesis by Anabaena sp. Water Res 35:1209-1218

Sarker PK, Fukada H, Hosokawa H, Masumoto T (2006) Effects of phytase with inorganic phosphorus supplement diet on nutrient availability of Japanese flounder (Paralichthys olivaceus). Aquacult Sci 54:391-398

Sarker PK, Shuichi S, Fukada H, Masumoto T (2009) Effects of dietary phosphorus level on non-faecal phosphorus excretion from yellowtail (Seriola quinqueradiata Temminck \& Schlegel) fed purified and practical diets. Aquacult Res 40:225-232

Sarker PK, Fournier J, Boucher E, Proulx E, Noüe J, Vandenberg GW (2011) Effects of low phosphorus ingredient combinations on weight gain, apparent digestibility coef- 
ficients, non-fecal phosphorus excretion, phosphorus retention and loading of large rainbow trout (Oncorhynchus mykiss). Anim Feed Sci Technol 168:241-249

Sarker PK, Bureau DP, Hua K, Drew MD and others (2013) Sustainability issues related to feeding salmonids: a Canadian perspective. Rev Aquacult 5:199-219

Schindler DW (1977) Evolution of phosphorus limitation in lakes. Science 195:260-262

Schrader KK, Blevins WT (2001) Effects of carbon source, phosphorus concentration, and several micronutrients on biomass and geosmin production by Streptomyces halstedii. J Ind Microbiol Biotechnol 26:241-247

Schrader KK, Rimando AM (2003) Off-flavors in aquaculture: an overview. In: Rimando AM, Schrader KK (eds) Off-flavors in Aquaculture. The American Chemical Society Symposium, Series 848. Oxford University Press, Washington, DC, p 1-12

Schrader KK, Summerfelt ST (2010) Distribution of off-flavor compounds and isolation of geosmin-producing bacteria in a series of water recirculating systems for rainbow trout culture. N Am J Aquacult 72:1-9

Shnel N, Barak Y, Ezer T, Dafni Z, van Rijn J (2002) Design and performance of a zero-discharge tilapia recirculating system. Aquacult Eng 26:191-203

Smith VH, Bennett SJ (1999) Nitrogen:phosphorus supply ratios and phytoplankton community in lakes. Arch Hydrobiol 146:37-53

Sugiura N, Nakano K (2000) Causative microorganisms for musty odor occurrence in the eutrophic Lake Kasumigaura. Hydrobiologia 434:145-150
Sugiura SH, Dong FM, Hardy RW (2000) A new approach to estimating the minimum dietary requirement of phosphorus for large rainbow trout based on non-fecal excretions of phosphorus and nitrogen. J Nutr 130:865-872

Sugiura SH, McDaniel NK, Ferraris RP (2003) In vivo fractional Pi absorption and NaPi-II mRNA expression in rainbow trout are unregulated by dietary $\mathrm{P}$ restriction. Am J Physiol Regul Integr Comp Physiol 285:R770-R781

Tucker CS (2000) Off-flavor problems in aquaculture. Rev Fish Sci 8:45-88

Tucker CS, Martin JF (1991) Environment-related offflavors in fish. In: Brune DE, Tomasso JR (eds) Aquaculture and water quality. Advances in World Aquaculture, Vol. 3. The World Aquaculture Society, Baton Rouge, LA, p 133-179

Vallod D, Cravedi JP, Hillenweck A, Robin J (2007) Analysis of the off-flavor risk in carp production in ponds in Dombes and Forez (France). Aquacult Int 15:287-298

Vielma J, Lall SP (1998) Phosphorus utilization by Atlantic salmon (Salmo salar) reared in freshwater is not influenced by higher dietary calcium intake. Aquaculture 160:117-128

Weinberg ED (1989) Roles of micronutrients in secondary metabolism of actinomycetes. In: Shapiro S (ed) Regulation of secondary metabolism in Actinomycetes. CRC Press, Boca Raton, FL, p 239-261

> Zimba PV, Mischke CC, Dionigi CP, Brashear SS (2003) Pond age-water column trophic relationships in channel catfish Ictalurus punctatus production ponds. Aquaculture 219:291-301

Appendix. Ion chromatography methods. Inorganic anions included chloride, nitrate, nitrite, phosphate and sulfate; inorganic cations included calcium, magnesium, potassium and sodium; metals included iron (III) and the divalent cations of copper and zinc

\begin{tabular}{|c|c|}
\hline & Conditions \\
\hline \multicolumn{2}{|l|}{ Anions } \\
\hline Volume injected & $50 \mu \mathrm{l}$ \\
\hline Analytical column & IonPac AS17 $(4 \times 250 \mathrm{~mm})$ \\
\hline Guard column & AG17 $(4 \times 50 \mathrm{~mm})$ \\
\hline Eluent gradient & Potassium hydroxide (9 to $30 \mathrm{mM}$ ), $16 \mathrm{~min}$ \\
\hline Standard flow rate & $1 \mathrm{ml} \mathrm{min}^{-1}$ \\
\hline Temperature & $30^{\circ} \mathrm{C}$ \\
\hline Suppressor & Anion self-regenerating suppressor (ASRS ULTRA II, $-4 \mathrm{~mm}$ ) \\
\hline \multicolumn{2}{|l|}{ Cations } \\
\hline Volume injected & $50 \mu \mathrm{l}$ \\
\hline Analytical column & IonPac CS16 $(5 \times 250 \mathrm{~mm})$ \\
\hline Guard column & CG16 $(5 \times 50 \mathrm{~mm})$ \\
\hline Eluent & Methanesulfonic acid (MSA) (42 mM), 16 min \\
\hline Standard flow rate & $1 \mathrm{ml} \mathrm{min}^{-1}$ \\
\hline Temperature & $30^{\circ} \mathrm{C}$ \\
\hline Suppressor & Cation self-regenerating suppressor (CSRS ULTRA II, $-4 \mathrm{~mm}$ ) \\
\hline \multicolumn{2}{|l|}{ Metals } \\
\hline Volume injected & $50 \mu \mathrm{l}$ \\
\hline Analytical column & IonPac CS5A $(4 \times 250 \mathrm{~mm})$ \\
\hline Guard column & CG5A $(4 \times 50 \mathrm{~mm})$ \\
\hline Eluent & MetPac PDCA eluent (5×) \\
\hline Standard flow rate & $1.2 \mathrm{ml} \mathrm{min}{ }^{-1}$ \\
\hline Post-column reagent & PAR (0.5 mM) \\
\hline Reagent flow rate & $0.7 \mathrm{ml} \mathrm{min}-1$ \\
\hline Detector wavelength & $520 \mathrm{~nm}$ \\
\hline
\end{tabular}

